\title{
ANALISIS PENGARUH KARAKTERISTIK PERUSAHAAN DAN TATA KELOLA PERUSAHAAN TERHADAP PENGUNGKAPAN SUSTAINABILITY REPORT
}

\author{
Robby Krisyadi* dan Elleen* \\ *Program Studi Akuntansi, Fakultas Ekonomi \\ Universitas Internasional Batam \\ Email:robby.krisyadi@uib.ac.id; elleenn.blue98@gmail.com
}

\begin{abstract}
The objective of this study is to examine and analyze the correlation of company characteristics and corporate governance towards sustainability report disclosure. The company characteristics mentioned before consist of company size, leverage level, profitability level, and liquidity level, while the corporate governance consist of the board of directors's meeting frequency and audit committee's meeting frequency.

Companies listed in the Indonesia Stock Exchange from 2014 to 2018 are the objects of this research. Data that needs to be collected are financial reports, annual reports, and sustainability reports if available. Purposive sample is the sampling technique used in this study by establishing certain characteristics that are in line with the objectives of the study. There are 301 companies used as samples. The data that has been collected will then be processed with a software called SPSS Version 22 which is analyzed with the logistic regression model.

The test results in this study explain that company size, profitability, and the board of directors have a positive effect on sustainability report disclosure, while leverage and the audit committee don't have any significant effects on the sustainability report disclosure. In addition, there are also significant negative results indicated by the liquidity variable on the sustainability report disclosure. This is triggered by the company's poor financial condition, so companies with low liquidity tend to disclose more additional information such as sustainability reports so that investors will continue to invest in the company.
\end{abstract}

Keywords: sustainability report disclosure, company characteristics, corporate governance.

\section{PENDAHULUAN}

Memaksimalkan keuntungan yang diperoleh serta memperbaiki kualitas perusahaan ke arah yang lebih baik merupakan tujuan pokok dari setiap perusahaan. Guna keberhasilan pencapaian tujuan, perusahaan perlu melakukan pencatatan aktivitas keuangan untuk dijadikan acuan oleh para pemegang saham untuk mengukur nilai perusahaan. Segala jenis perusahaan dituntut untuk dapat menghasilkan catatan keuangan yang biasa disebut sebagai laporan keuangan (Karnawiredja, Hidayat, \& Effendy, 2013). Laporan keuangan adalah produk final yang dihasilkan dari proses aktivitas akuntansi yang disusun rapi guna dijadikan sebagai sumber informasi terkait kondisi keuangan perusahaan pada periode akuntansi tertentu kepada para pihak yang berkepentingan atas informasi tersebut (Wantah, 2015). Pada umumnya, laporan keuangan hanya menyediakan informasi-informasi dari sisi keuangan. Hal tersebut tentu belum cukup bagi para pemangku kepentingan untuk melihat dan mengukur nilai suatu perusahaan secara menyeluruh karena laporan tersebut belum dapat menunjukkan tanggung jawab perusahaan terhadap pemegang saham, karyawan, masyarakat, dan konsumen sehingga diperlukan adanya laporan lain untuk mendukung pengungkapan laporan keuangan (Aziz, 2014).

Laporan lain yang dimaksudkan untuk mendapatkan informasi mengenai 
segala kegiatan perusahaan yang berhubungan dengan tanggung jawab lingkungan dan sosial ini dikenal dengan sebutan sustainability report. Sustainability report ini diharapkan dapat menjadi satu alat untuk mendukung keberlangsungan hidup perusahaan (Tarigan \& Semuel, 2015). Sustainability report memiliki banyak sekali definisi, salah satunya diungkapkan oleh Elkington (dalam Semuel \& Saridewi, 2015) yang mengartikan sustainability report sebagai laporan yang memberikan peluang bagi perusahaan untuk bertumbuh secara berkesinambungan

(sustainable performance) dengan cara menampilkan informasi kinerja keuangan dan informasi kinerja non-keuangan seperti informasi kegiatan lingkungan dan sosial. Disebutkan juga bahwa dalam dunia usaha, kinerja perusahaan tidak hanya perlu diukur dari sisi keuangannya saja, tetapi juga perlu diukur dari tiga konsep yang dikenal sebagai konsep Tripple-P Bottom Line. Konsep yang terdiri dari keuntungan (profit), bumi (planet), dan komunitas (people) dipakai oleh para manajer perusahaan untuk mencapai pembangunan keberlanjutan (sustainability development).

Sustainability report di Indonesia merupakan pelaporan yang masih sebatas bersifat sukarela (voluntary). Hal ini menjelaskan bahwa perusahaan boleh tidak menerbitkan sustainability report karena masih belum ada aturan baku yang mengharuskan penerbitan laporan tersebut seperti halnya pada penerbitan financial report (Fatchan \& Trisnawati, 2016). Menurut Otoritas Jasa Keuangan (OJK), meski masih bersifat sukarela, sudah terdapat kira-kira $9 \%$ perusahaan yang telah menerbitkan sustainability report dan terus meningkat setiap tahunnya dikarenakan banyak investor yang mulai menginginkan adanya sustainability report pada suatu perusahaan. Hal tersebut didukung dengan tumbuhnya kesadaran investor akan pentingnya hubungan antara perusahaan dengan lingkungannya guna mengetahui tentang produk yang dihasilkan oleh perusahaan tersebut diterima secara ramah oleh masyarakat atau tidak.

Terdapat beberapa elemen yang dapat mempengaruhi pengungkapan sustainability report ini, salah satunya adalah karakteristik perusahaan. Menurut Surbakti (2012) yang dikutip dalam Dewi dan Jati (2014), pengertian dari karakteristik perusahaan adalah sifat unik dari suatu entitas usaha yang pastinya berbeda bagi setiap perusahaan. Karakteristik tersebut dapat dilihat dari berbagai macam komponen seperti ukuran perusahaan, tingkat leverage, tingkat profitabilitas, dan tingkat likuiditas.

Selain itu, tata kelola perusahaan yang juga mempengaruhi pengungkapan sustainability report dapat didefinisikan sebagai rangkaian proses, aturan, serta kebijakan yang berpengaruh terhadap pengarahan, pengelolaan, hingga ke pengontrolan suatu entitas usaha. Pihakpihak yang pada umumnya terlibat dalam tata kelola perusahaan ini yakni para pemangku kepentingan seperti pemegang saham, manajemen, serta dewan direksi (Pertiwi \& Pratama, 2011). Dalam penelitian ini, dewan direksi dan komite audit merupakan komponen yang dipergunakan dari tata kelola perusahaan.

\section{KAJIAN LITERATUR PENGEMBANGAN HIPOTESIS}

Pembangunan berkerlanjutan bertujuan untuk memenuhi kebutuhan hidup manusia dengan memberikan perhatian lebih terhadap aspek lingkungan dan juga sosial. Demi tercapainya tujuan tersebut, maka diterbitkanlah sustainability report untuk menilai kinerja perusahaan terhadap lingkungan yang dapat digunakan untuk mendapatkan perhatian dari investor untuk menanamkan modalnya di perusahaan yang jauh dari risiko sosial dan lingkungan.

Menurut Otoritas Jasa Keuangan (OJK), sustainability report adalah suatu bentuk laporan yang dirancang dan dibuat oleh suatu badan usaha untuk dapat ditunjukkan dan dikomunikasikan dengan pihak-pihak yang berkepentingan terkait kinerja Lingkungan, Sosial, dan Tata Kelola 
(LST) yang baik. Suatu jenis pelaporan yang masih memiliki sifat sukarela dengan tujuan guna mewujudkan tanggung jawab terhadap lingkungan serta masyarakat merupakan definisi dari sustainability report yang disebutkan oleh Sari (2013). Disebutkan juga terkait pentingnya penerbitan sustainability report guna mendapatkan pengakuan dari para pemangku kepentingan dan masyarakat bahwa perusahaan telah melaksanakan tanggung jawabnya dengan baik kepada lingkungan dan masyarakat.

Sustainability report dilaporkan berlandaskan standar yang dapat ditemui pada Global Reporting Index (GRI) yang didirikan di tahun 1997. GRI menyajikan kerangka kerja untuk pelaporan sustainability report yang bisa digunakan oleh segala jenis organisasi di dunia. Setelah dibentuk, GRI menerbitkan panduan sustainability report untuk pertama kalinya pada tahun 2000. Kemudian dilakukan revisi di tahun 2002 dengan menerbitkan GRI G-2, GRI G-3 di tahun 2006, GRI G-3.1 di tahun 2011 dan standar GRI versi paling baru yaitu GRI G-4 di tahun 2013.

GRI G-4 menyediakan pedoman mengenai cara mengungkapkan keberlanjutan dalam kerangka kerja yang relevan guna mendukung pendekatan yang terstandarisasi dalam pelaporan sehingga dapat meningkatkan tingkat konsistensi dan transparansi. Terdapat tiga kelompok indikator kerja standar GRI G-4, yaitu ekonomi, lingkungan, dan sosial.

Terdapat dua landasan teori yang mendasari sustainability report, yaitu teori stakeholder dan teori legitimasi. Teori yang memiliki korelasi dengan konsep tanggung jawab sosial perusahaan yang keberlangsungan hidup entitasnya dipengaruhi oleh pemangku kepentingan merupakan definisi dari teori stakeholder. Teori ini juga menjelaskan bahwa selain memaksimalkan pendapatan yang diperoleh perusahaan dan memperhatikan kepentingan pemegang saham, perusahaan juga mempunyai tanggung jawab untuk memberikan perhatiannya kepada masyarakat, konsumen, serta pemasok (Paramita et al., 2013).

Menurut Deegan, Robin, dan Tobin (2002) yang dikutip dari Aziza (2014), legitimasi suatu badan usaha akan dapat diperoleh apabila terdapat keserupaan antara hasil yang diberikan perusahaan dengan harapan dari masyarakat, sehingga masyarakat tidak akan lagi menuntut hal-hal yang tidak sesuai harapan. Perusahaan akan ditempatkan pada posisi yang buruk apabila terdapat ketidaksamaan antara nilai yang digunakan oleh perusahaan dengan nilai yang digunakan oleh masyarakat. Ketidaksamaan tersebut biasa disebut sebagai legitimacy gap yang memberi dampak pada kemampuan perusahaan dalam meneruskan aktivitas usahanya. Apabila gap tersebut sudah muncul, maka perusahaan perlu memantau dan mengevaluasi lagi faktor pemicu gap tersebut dapat terjadi. Legitimacy gap bisa diperkecil dengan cara melakukan peningkatan pada tanggung jawab sosial dan pengungkapan sosial (O'Donovan, 2002).

\section{Ukuran Perusahaan terhadap Pengungkapan Sustainability Report \\ Gallo dan Christensen (2011)}

menyatakan dalam risetnya bahwa semakin besar ukuran suatu perusahaan, maka keinginan perusahaan dalam menghasilkan sustainability report akan semakin meningkat. Hal tersebut dipicu oleh kecenderungan perusahaan besar yang lebih memperhatikan pengakuan dan penerimaan masyarakat terhadap perusahaan yang bisa didapatkan dari penerbitan sustainability report. Hasil riset tersebut searah dengan riset-riset yang telah dikaji oleh Legendre dan Coderre (2013), Bhatia dan Tuli (2017), Dibia dan Nwaigwe (2018) yang menyatakan adanya keterkaitan dengan arah positif antara variabel ukuran perusahaan dengan variabel pengungkapan sustainability report.

$\mathrm{H}_{1}$ : Ukuran perusahaan berpengaruh positif terhadap pengungkapan sustainability report. 


\section{Leverage terhadap Pengungkapan Sustainability Report}

Pada studi yang telah dikaji oleh Branco, Delgado, Gomes, dan Eugénio (2014), dinyatakan bahwa diperlukan biaya yang besar dalam mengungkapkan sustainability report, sehingga perusahaan dengan leverage tinggi memiliki kecenderungan untuk meminimalisir pengeluaran biaya yang dapat menambah jumlah utang perusahaan, salah satu biaya yang dimaksud adalah biaya penerbitan sustainability report. Hasil ini searah dengan riset yang telah dikemukakan oleh Bhatia dan Tuli (2017), Diantimala dan Amril (2018), dan Liana (2019) yang memaparkan bahwa leverage berhubungan negatif dengan pengungkapan sustainability report.

$\mathrm{H}_{2}$ : Leverage berpengaruh negatif terhadap pengungkapan sustainability report.

\section{Profitabilitas terhadap Pengungkapan Sustainability Report}

Almilia (2008), Shum, Chen, dan Burritt (2009), Yasmin dan Zuraida (2017), Benjamin, Okpanachi, dan Muhammad (2017), dan Elshabasy (2018) dalam penelitiannya mengungkapkan bahwa terdapat korelasi positif antara profitabilitas dengan variabel dependen pengungkapan sustainability report. Dijelaskan bahwa terdapat kecenderungan bagi perusahaan berprofitabilitas tinggi untuk menguak informasi tambahan kepada publik dan para pemangku kepentingan karena perusahaan mampu menerbitkan sustainability report yang memerlukan biaya besar, sedangkan perusahaan dengan nilai profitabilitas yang rendah biasanya lebih fokus dalam meningkatkan profit perusahaan daripada menerbitkan sustainability report yang dapat semakin mengurangi profit yang diperoleh.

$\mathrm{H}_{3}$ : Profitabilitas berpengaruh positif terhadap pengungkapan sustainability report.

\section{Likuiditas terhadap Pengungkapan Sustainability Report}

Saputro, Fachrurrozie, dan Agustina (2013) menjelaskan bahwa rasio likuiditas dapat digunakan sebagai cerminan kesehatan keuangan suatu badan usaha, artinya badan usaha dengan likuiditas tinggi memiliki kondisi keuangan yang sehat, begitu pula sebaliknya. Perusahaan berlikuiditas tinggi memiliki kecenderungan untuk mencurahkan lebih banyak informasi, salah satunya adalah melalui sustainability report. Berbanding terbalik dengan perusahaan dengan kondisi keuangan lemah yang akan lebih fokus untuk memperbaiki kinerja ekonomi mereka daripada memberikan perhatian terhadap lingkungan. Yasmin dan Zuraida (2017), Diantimala (2018), Badawi dan Nugroho (2019) juga memaparkan hal yang sama terkait adanya hubungan positif antara likuiditas dengan pengungkapan sustainability report.

$\mathrm{H}_{4}$ : Likuiditas berpengaruh positif terhadap pengungkapan sustainability report.

\section{Dewan Direksi terhadap Pengungkapan Sustainability Report}

Berdasarkan riset yang dikemukakan oleh Suryono dan Prastiwi (2011) yang bertujuan untuk menganalisa ketidaksamaan antara entitas yang mengungkapkan sustainability report dengan entitas yang tidak mengungkapkannya berdasarkan karakteristik dan tata kelola perusahaan, disebutkan bahwa dalam mewujudkan Good Corporate Governance (GCG), dibutuhkan kinerja dewan yang baik. Jumlah rapat antar dewan direksi menunjukkan sering atau tidaknya dilakukan komunikasi dan koordinasi antar dewan. Artinya, semakin banyak rapat yang diselenggarakan oleh direksi, semakin sering pula diadakannya komunikasi yang dapat memudahkan tercapainya GCG, sehingga tingkat diungkapkannya informasi juga akan meningkat. Pernyataan ini searah dengan riset yang telah dikemukakan oleh Khafid (2012), Sari dan Marsono (2013), dan Awalia et al. (2015) yang menjelaskan adanya hubungan yang positif antara dewan direksi dengan pengungkapan sustainability report. $\mathrm{H}_{5}$ : Dewan direksi berpengaruh positif terhadap pengungkapan sustainability report. 
Komite Audit terhadap Pengungkapan Sustainability Report

Menurut Anikita dan Khafid (2015)

dalam penelitiannya menyebutkan bahwa komite audit memberi pengaruh dengan arah positif terhadap tingkat dipublikasikan atau tidak dipublikasikannya sustainability report karena komite audit yang berkualitas akan dapat lebih mengerti tentang strategi pengungkapan informasi. Semakin banyak jumlah pertemuan, maka semakin mampu juga komite audit dalam mendorong manajemen untuk mempublikasikan sustainability report yang bisa dijadikan sarana bagi perusahaan untuk memperoleh legitimasi. Hal ini sejalan dengan penelitian Wang (2017), Buallay dan AlDhaen (2018), Dizar, Alifia, dan Alvionita (2019) yang menjelaskan bahwa komite audit berhubungan positif dengan pengungkapan sustainability report.

$\mathrm{H}_{6}$ : Komite audit berpengaruh positif signifikan terhadap pengungkapan sustainability report.

\section{METODE PENELITIAN}

Penelitian yang bertujuan untuk mengembangkan teori yang sudah ada sebelumnya ini memiliki sifat kuantitatif, maksudnya adalah jenis data yang digunakan berwujud angka atau bilangan. Pada penelitian ini, juga digunakan jenis data time series karena data yang diambil untuk diamati adalah lebih dari satu periode, yaitu dari tahun 2014 hingga 2018.

Bila dinilai dari segi karakteristiknya, penelitian ini dapat digolongkan sebagai penelitian komparatif yang pengertiannya dinyatakan oleh Indriantoro dan Supomo (2002) sebagai penelitian yang bertujuan untuk mencari jawaban mengenai kemungkinan terjadinya hubungan sebab akibat antar variabel.

\section{Sustainability Report}

Variabel dependen pada penelitian ini ialah pengungkapan sustainability report. Metode perhitungannya adalah dengan memberi kode 0 pada perusahaan yang tidak menerbitkan sustainability report dan kode 1 pada perusahaan yang menerbitkan sustainability report (Lucia \& Panggabean, 2018).

\section{Ukuran Perusahaan}

Ukuran perusahaan ialah suatu skala yang dapat mengelompokkan suatu badan usaha ke dalam dua kelompok, perusahaan berskala besar dan perusahaan berskala kecil (Prasetyorini, 2013). Pengukuran yang diaplikasikan pada penelitian ini mempunyai rumus sebagai berikut (Lucia \& Panggabean, 2018):

$$
S I Z E=L n(\text { Total Aset })
$$

\section{Leverage}

Leverage ialah suatu rasio keuangan dengan fungsi untuk menakar kemampuan suatu badan usaha dalam membayar kewajiban jangka panjangnya. Berikut adalah rumus dari leverage menurut Lucia dan Panggabean (2018):

$$
\text { Leverage }=\frac{\text { Total Utang }}{\text { Total Aset }}
$$

\section{Profitabilitas}

Profitabilitas dikenal sebagai rasio pengukur kemampuan suatu badan usaha dalam rangka mendapatkan keuntungan atau juga dapat disebut sebagai kemampuan dari investasi yang diberikan untuk mendapatkan pengembalian dari penggunanya (Tulsian, 2014). Rincian rumus profitabilitas adalah sebagai berikut (Lucia \& Panggabean, 2018):

$$
R O A=\frac{\text { Laba Bersih }}{\text { Total Aset }}
$$

\section{Likuiditas}

Likuiditas disebut sebagai rasio yang dapat memperlihatkan kemampuan suatu badan usaha dalam memaksimalkan aset lancar pada neraca guna memenuhi kewajiban jangka pendeknya (Puspasari, 2017). Jenis pengukuran yang diaplikasikan pada penelitian ini adalah dengan menggunakan Current Ratio (CR) dengan rincian rumus sebagai berikut (Lucia \& Panggabean, 2018):

$$
C R=\frac{\text { Aset Lancar }}{\text { Kewajiban Lancar }}
$$




\section{Dewan Direksi}

Dewan direksi dapat diartikan sebagai pemimpin dari suatu badan usaha yang ditetapkan oleh para pihak pemegang saham untuk dijadikan perwakilan mereka terkait masalah pengelolaan perusahaan (Jan \& Sangmi, 2016). Pengukuran dewan direksi dilakukan dengan melihat frekuensi rapat antar anggota direksi setiap tahunnya (Lucia \& Panggabean, 2018).

\section{Komite Audit}

Komite audit adalah beberapa dari anggota direksi suatu badan usaha yang dipilih guna memberikan kemudahan kepada auditor dalam mempertahankan independensinya dari manajemen (Malik, 2014). Pengukuran variabel komite audit yang diaplikasikan pada penelitian ini adalah dengan menghitung jumlah rapat antar komite audit per tahun (Lucia \& Panggabean, 2018).

\section{HASIL PENELITIAN}

\section{Statistik Deskriptif}

Penelitian ini mempergunakan data berbentuk sekunder sebagai dasar Tabel 2

Hasil Uji Statistik Deskriptif Variabel Independen

\begin{tabular}{|l|r|r|r|r|r|}
\hline \multicolumn{1}{|c|}{ Variabel } & N & \multicolumn{1}{c|}{ Minimum } & Maksimum & \multicolumn{1}{c|}{ Rata-Rata } & \multicolumn{1}{c|}{ Std. Deviasi } \\
\hline Ukuran Perusahaan (dalam jutaan) & 1400 & 17.533 & 344.711 .000 & 9.993 .414 & 22.905 .093 \\
\hline Leverage & 1400 & 0,011209 & 1,492332 & 0,487293 & 0,226407 \\
\hline Profitabilitas & 1400 & $-0,376701$ & 0,431698 & 0,030722 & 0,087245 \\
\hline Likuiditas & 1400 & 0,011643 & 62,960196 & 2,393817 & 4,056713 \\
\hline Dewan Direksi & 1400 & 1,000000 & 57,000000 & 17,660000 & 11,932000 \\
\hline Komite Audit & 1400 & 1,000000 & 29,000000 & 6,090000 & 3,775000 \\
\hline
\end{tabular}

Sumber: Data sekunder diolah, 2020.

Perusahaan yang menunjukkan ukuran perusahaan terbesar berdasarkan hasil uji di atas adalah PT. Astra International Tbk dengan total aset sebesar Rp344.711.000.000.000 di tahun 2018, sedangkan perusahaan yang menunjukkan ukuran perusahaan terkecil adalah PT. Akbar Indomakmur Stimec Tbk dengan total aset sebesar Rp 17.533.206.467 di tahun 2018. Seperti yang telah tercantum pada Pasal 1 Keputusan Ketua Badan Pengawas Pasar Modal Nomor KEP-11/PM/1997 bahwa suatu perusahaan dapat digolongkan sebagai perusahaan berukuran besar apabila pengujiannya. Objek penelitian yang digunakan adalah laporan tahunan perusahaan di Indonesia yang tercatat di dalam BEI dari periode tahun 2014 hingga 2018. Data-data yang bersangkutan kemudian diolah dengan memanfaatkan software SPSS Versi 22.

Tabel 1

\section{Rincian Pemilihan Sampel}

\begin{tabular}{|l|c|}
\hline \multicolumn{1}{|c|}{ Keterangan } & Jumlah \\
\hline Perusahaan yang tercatat di BEI & 615 \\
\hline $\begin{array}{l}\text { Perusahaan yang terdaftar setelah } \\
\text { tahun 2014 }\end{array}$ & $(136)$ \\
\hline Perusahaan financial & $(93)$ \\
\hline $\begin{array}{l}\text { Perusahaan yang tidak memenuhi } \\
\text { kriteria }\end{array}$ & $(85)$ \\
\hline Perusahaan yang dijadikan sampel & 301 \\
\hline Tahun penelitian & 5 \\
\hline Jumlah data penelitian & 1.505 \\
\hline Jumlah data outlier & $(105)$ \\
\hline Jumlah data pengujian & 1.400 \\
\hline
\end{tabular}

Sumber: Data sekunder diolah, 2020.

Tabel 2 di bawah memperlihatkan secara jelas ringkasan karakteristik data penelitian dari tiap-tiap variabelnya yang berupa nilai terendah, nilai tertinggi, nilai rata-rata, dan nilai standar deviasi. 
leverage dengan nilai 0,49 menjelaskan bahwa leverage perusahaan sampel masih tergolong rendah. Semakin rendah nilai leverage maka semakin rendah pula jumlah aset yang dimanfaatkan untuk membiayai utang.

Variabel

profitabilitas

memperlihatkan nilai rata-rata sebesar 0,03 , maksudnya adalah setiap satu rupiah aset yang dimiliki perusahaan mampu menghasilkan laba sebanyak 0,03. Hal ini menggambarkan bahwa masih lebih banyak perusahaan sampel yang mengalami keuntungan daripada perusahaan yang mengalami kerugian. Tingkat profitabilitas terendah dipegang oleh PT. Central Proteina Prima Tbk yang memiliki total rugi sebesar Rp 2.639.420.000.000 dan nilai sebesar -0,38 yang artinya perusahaan tersebut menerima kerugian sebesar -0,38 dari setiap satu rupiah aset yang dimilikinya. Nilai maksimum sebesar 0,43 dicapai oleh PT. Multi Bintang Indonesia Tbk dengan laba sebesar Rp 1.322.067.000.000 dan jumlah aset sebesar Rp 2.510.078.000.000.

Variabel likuiditas yang menggunakan rasio lancar sebagai alat ukurnya memiliki nilai maksimum sebesar 62,96 yang artinya bahwa setiap satu rupiah utang lancar dijamin oleh 62,96 rupiah aset lancar. PT. Tanah Laut Tbk merupakan pemilik dari nilai tersebut dengan nilai aset lancar sebesar $\mathrm{Rp}$ 77.380.231.156 dan liabilitas lancar sebesar $\mathrm{Rp}$ 1.229.034.146. Nilai terendah variabel ini ialah sebesar 0,01 , maksudnya adalah setiap satu rupiah utang Tabel 3

Hasil Uji Statistik Deskriptif Variabel Dependen

\begin{tabular}{|c|l|c|c|}
\hline Kariabel & Kategori & Frekuensi & Persentase \\
\hline $\begin{array}{c}\text { Pengungkapan sustainability } \\
\text { report }\end{array}$ & $0=$ Tidak menerbitkan sustainability report & 1.268 & $90,60 \%$ \\
\cline { 2 - 4 } & 1 = Menerbitkan sustainability report & 132 & $9,40 \%$ \\
\hline
\end{tabular}

Sumber: Data sekunder diolah, 2020.

Tabel 3 memperlihatkan persentase perusahaan yang menerbitkan sustainability report sebesar $9,40 \%$ dari jumlah data yang dijadikan sampel atau sebanding dengan 132 data sampel. Juga dijelaskan bahwa terdapat $90,60 \%$ dari jumlah data yang dijadikan sampel atau sama dengan 1.268 data sampel tidak menerbitkan sustainability report, maka lancar hanya dapat dijamin oleh aset lancar sebanyak 0,01 rupiah, sedangkan nilai rataratanya adalah di atas 1,00, yaitu sebesar 2,39. Hal ini menjelaskan bahwa lebih banyak perusahaan sampel yang memiliki kemampuan untuk melunasi utang jangka pendeknya tanpa adanya kegiatan operasional yang terganggu.

Rata-rata variabel dewan direksi dengan alat ukur berupa frekuensi rapat yang dilaksanakan setiap tahunnya adalah sebanyak 17,66 atau sama dengan 18 kali rapat. Jumlah rapat minimum yang dilakukan oleh direksi adalah sebanyak 1 kali pertemuan sedangkan jumlah rapat maksimumnya adalah sebanyak 57 kali pertemuan. Hal ini menunjukkan bahwa belum semua perusahaan menjalankan POJK No.33/POJK.04/2014 pasal 16 yang menjelaskan bahwa dewan direksi perlu mengadakan pertemuan minimal sekali dalam sebulan.

Rata-rata variabel komite audit dengan alat ukur berupa frekuensi pertemuan yang diselenggarakan setiap tahunnya adalah sebanyak 6,09 kali atau sama dengan 6 kali rapat. Frekuensi rapat terkecil yang diselenggarakan adalah sebanyak 1 pertemuan, sedangkan frekuensi terbanyaknya adalah sejumlah 29 kali pertemuan. Hal ini menandakan bahwa belum semua perusahaan mematuhi POJK No.55/POJK.04/2015 pasal 13 yang menyatakan bahwa komite audit perlu menyelenggarakan pertemuan paling kurang sekali dalam kurun waktu 3 bulan. 
mengikuti sebagian besar pola atau menyimpang jauh dari rata-rata yang dapat membuat hasil analisis menjadi bias. Hasil pengujian pada 1.505 data sampel menunjukkan bahwa terdapat sebanyak 105 data yang menyimpang, sehingga data outlier tersebut dibuang dan tersisa data setelah outlier dibuang adalah sebanyak 1.400 data.

\section{Uji Multikolinieritas}

Uji multikolinieritas dilakukan guna memperlihatkan terdapat atau tidak terdapatnya ikatan antar variabel bebasnya yang dapat ditentukan dari nilai pearson correlation-nya. Tabel 4 di bawah memperlihatkan hasil uji dari setiap variabel bebasnya dan didapatkan bahwa tidak ada satu pun variabel bebas yang mengalami multikolinieritas. Pernyataan tersebut dibuktikan dengan tidak adanya nilai pearson correlation yang berada di atas angka 0,80 . Berikut adalah rincian nilai pearson correlation antar variabel bebasnya:

Tabel 4

Hasil Uji Multikolinieritas

\begin{tabular}{|l|l|l|l|l|l|l|}
\hline \multicolumn{1}{|c|}{ Variabel } & \multicolumn{1}{c|}{ a. } & b. & \multicolumn{1}{c|}{ c. } & \multicolumn{1}{c|}{ d. } & e. & f. \\
\hline a. Ukuran Perusahaan & 1,000 & & & & & \\
\hline b. Leverage & $0,198^{* *}$ & 1,000 & & & & \\
\hline c. Profitabilitas & $0,119^{* *}$ & $-0,287^{* *}$ & 1,000 & & & \\
\hline d. Likuiditas & $-0,213^{* *}$ & $-0,412^{* *}$ & $0,080^{* *}$ & 1,000 & & \\
\hline e. Dewan Direksi & $0,153^{* *}$ & $0,099^{* *}$ & $0,055^{*}$ & $-0,078^{* *}$ & 1,000 & \\
\hline f. Komite Audit & $0,263^{* *}$ & $0,090^{* *}$ & 0,016 & $-0,072^{* *}$ & $0,239^{* *}$ & 1,000 \\
\hline
\end{tabular}

*korelasi signifikan antar variabel bebas dengan sig. $<0,05$

**korelasi signifikan antar variabel bebas dengan sig. $<0,01$

Sumber: Data sekunder diolah, 2020.

\section{Uji Hipotesis}

\section{Uji Hosmer and Lemeshow}

Pengujian Hosmer and Lemeshow dilakukan guna melihat tingkat kesinambungan data dengan model. Hasil uji Hosmer and Lemeshow memperlihatkan nilai signifikansi yang jauh melampaui angka 0,05, yaitu sebesar 0,312. Hasil ini membuktikan adanya kesesuaian model regresi dengan data sehingga dapat digunakan dalam pengujian hipotesis. Berikut adalah rincian hasil ujinya:

Tabel 5

Hasil Uji Hosmer and Lemeshow

\begin{tabular}{|l|c|c|}
\hline \multicolumn{1}{|c|}{ Variabel Dependen } & Chi-square & Sig. \\
\hline $\begin{array}{l}\text { Pengungkapan } \\
\text { sustainability report }\end{array}$ & 9,374 & 0,312 \\
\hline
\end{tabular}

Sumber: Data sekunder diolah, 2020.

\section{Uji Wald}

Tujuan dilaksanakannya pengujian Wald adalah untuk mengukur dan memeriksa pengaruh yang signifikan antara variabel bebas terhadap variabel terikatnya. Apabila signifikansi hasil pengujian variabel bebas bernilai kurang dari angka 0,05, maka variabel bebas dapat dikatakan berpengaruh terhadap variabel terikatnya. Pernyataan ini juga berlaku sebaliknya, apabila signifikansi hasil pengujian variabel bebas melampaui angka 0,05 , maka variabel bebas dapat dikatakan tidak berpengaruh terhadap variabel terikatnya. Nilai koefisien akan menjadi penentu signifikansi dengan arah negatif atau arah positif. Berikut adalah rincian hasil pengujian Wald: 
Tabel 6

Hasil Uji Wald

\begin{tabular}{|l|c|c|c|c|}
\hline \multicolumn{1}{|c|}{ Variabel } & Koef. & Sig. & Keterangan & Hipotesis \\
\hline Constant & $-41,900$ & 0,000 & & \\
\hline Ukuran Perusahaan (FSIZE) & 1,294 & 0,000 & Signifikan positif & Terbukti \\
\hline Leverage (LEV) & $-0,159$ & 0,832 & Tidak signifikan & Tidak terbukti \\
\hline Profitabilitas (PROF) & 5,557 & 0,000 & Signifikan positif & Terbukti \\
\hline Likuiditas (LIQ) & $-0,321$ & 0,009 & Signifikan negatif & Tidak terbukti \\
\hline Dewan Direksi (BOD) & 0,069 & 0,000 & Signifikan positif & Terbukti \\
\hline Komite Audit (AC) & $-0,005$ & 0,848 & Tidak signifikan & Tidak Terbukti \\
\hline
\end{tabular}

Sumber: Data sekunder diolah, 2020.

Bersumber pada Tabel 6, dijelaskan leverage dan komite audit tidak bahwa variabel independen ukuran mempengaruhi variabel dependen perusahaan, profitabilitas, likuiditas, dan pengungkapan sustaianability report. Berikut dewan direksi mempengaruhi variabel adalah persamaan regresi untuk penelitian dependen pengungkapan sustainability pengungkapan sustaianability report: report, sedangkan variabel independen

$$
S R=\frac{1}{1+e^{(-41,900+1,294 \mathrm{FSIZE}-0,159 \mathrm{LEV}+5,557 \mathrm{PROF}-0,321 \mathrm{LIQ}+0,069 \mathrm{BOD}-0,005 \mathrm{AC})}}
$$

Hasil uji pada Tabel 6 membuktikan adanya korelasi dengan arah positif antara ukuran perusahaan dengan pengungkapan sustainability report. Hasil tersebut dipicu oleh kecenderungan perusahaan besar yang lebih memperhatikan pengakuan dan penerimaan masyarakat terhadap perusahaan yang bisa didapatkan dari penerbitan sustainability report (Gallo \& Christensen, 2011). Penjelasan ini sesuai dengan argumen yang dikemukakan oleh Legendre dan Coderre (2013), Bhatia dan Tuli (2017), dan Dibia dan Nwaigwe (2018).

Nilai sig sebesar 0,832 didapatkan dari pengujian untuk variabel leverage, angka tersebut membuktikan bahwa tidak ditemukan korelasi yang signifikan antara leverage dengan pengungkapan sustainability report. Perusahaan dengan leverage tinggi maupun rendah tidak akan melakukan penerbitan sustainability report karena perusahaan tidak hendak menjadi sorotan dari debtholders yang dikatakan dapat semakin menekan manajemen apabila terlalu banyak berkutat dengan kegiatan-kegiatan sosial daripada memberi perhatian terhadap kepentingan mereka (Naidia, Wulandari, \& Septiani, 2017). Penjelasan ini konsisten dengan riset yang dilaksanakan oleh Artiach et al. (2010).

Terdapat pengaruh signifikan dengan arah positif dari profitabilitas terhadap variabel dependen pengungkapan sustainability report karena adanya kecenderungan bagi perusahaan dengan angka profitabilitas tinggi untuk menerbitkan lebih banyak informasi kepada publik dan para pemangku kepentingan karena perusahaan mampu menerbitkan sustainability report yang memerlukan biaya besar, sedangkan perusahaan dengan nilai profitabilitas yang rendah biasanya lebih fokus dalam meningkatkan profit perusahaan daripada menerbitkan sustainability report yang dapat semakin mengurangi profit yang diperoleh. Pernyataan tersebut serupa dengan argumen dari penelitian yang dikembangkan oleh Almilia (2008), Shum et al. (2009), Benjamin et al. (2017), dan Yasmin dan Zuraida (2017).

Likuiditas berhubungan negatif terhadap pengungkapan sustainability report karena perusahaan berlikuiditas tinggi cenderung untuk tidak menerbitkan sustainability report dan hanya mengungkapkan informasi seperlunya saja karena perusahaan berada dalam keadaan yang baik, sehingga perusahaan hanya akan melakukan pengungkapan sebatas untuk menambah image perusahaan saja. Sebaliknya, perusahaan berlikuiditas rendah memiliki kecenderungan untuk menuangkan lebih banyak informasi tambahan seperti sustainability report yang mampu menutupi 
kinerja keuangan yang buruk, sehingga investor masih ingin menanamkan modal pada perusahaan dan kelangsungan perusahaan pun menjadi terjaga Doktoralina et al. (2018).

Dewan direksi berpengaruh signifikan positif terhadap pengungkapan sustainability report karena jumlah rapat antar dewan direksi menunjukkan sering atau tidaknya dilakukan komunikasi dan koordinasi antar dewan. Artinya, semakin banyak rapat yang diadakan oleh direksi, semakin sering pula diadakannya komunikasi yang dapat memudahkan tercapainya GCG, sehingga tingkat diungkapkannya informasi juga akan meningkat (Suryono \& Prastiwi, 2011). Hasil ini searah dengan riset yang telah dikemukakan oleh Khafid (2012), Sari dan Marsono (2013), dan Sinaga dan Fachrurrozie (2017).

Nilai sig sebesar 0,848 didapatkan dari pengujian untuk variabel komite audit, angka tersebut membuktikan bahwa tidak ditemukan korelasi antara komite audit dengan pengungkapan sustainability report, sehingga dapat dikatakan bahwa hipotesis keenam ini tidak diterima. Hasil ini didukung dengan alasan bahwa komite audit biasanya lebih menempatkan fokus dalam meningkatkan kualitas pelaporan keuangan daripada melakukan pengungkapan tambahan seperti sustainability report. Pernyataan ini konsisten dengan studi yang pernah dijalankan oleh Khafid (2012), Adhipradana dan Daljono (2013), Sinaga dan Fachrurrozie (2017), Hasanah et al. (2017), dan Makhdalena (2019).

\section{KESIMPULAN}

Karya ilmiah ini memiliki maksud untuk menilik dan membahas elemen-elemen yang dapat dijadikan sebagai bahan pertimbangan oleh suatu perusahaan dalam hal pengambilan keputusan terkait penerbitan sustainability report. Setelah berbagai macam uji coba dilakukan, maka dapat ditarik sejumlah kesimpulan dari hasil uji serta pembahasannya, yaitu bahwa tidak ditemukan hubungan apapun antara leverage dan komite audit dengan tingkat pengungkapan sustainability report.

Didapatkan juga bahwa ukuran perusahaan, profitabilitas, dan dewan direksi berdampak signifikan positif terhadap pengungkapan sustainability report dan variabel likuiditas berdampak signifikan negatif terhadap pengungkapan sustainability report. Hal tersebut manandakan bahwa perusahaan kerap lebih mempertimbangkan dan memperhatikan jumlah keuntungan yang diperoleh, jumlah aset yang dimiliki, dan kemampuannya dalam memaksimalkan aset lancar yang dapat menjamin kewajiban lancarnya sebelum keputusan untuk menerbitkan sustainability report ditetapkan. Selain itu, masih belum tersedianya aturan baku terkait kewajiban untuk menerbitkan sustainability report menjadi faktor pemicu perusahaan untuk tidak terlalu memperhatikan laporan tersebut. Hal ini dibuktikan dengan masih sangat minimnya perusahaan di Indonesia yang menerbitkan sustainability report.

\section{Keterbatasan}

Berikut adalah sejumlah keterbatasan yang dapat ditemui pada penelitian ini:

1. Sampel penelitian yang dipergunakan hanya sebanyak 301 perusahaan dari total 615 perusahaan yang tercatat di BEI.

2. Adanya keterbatasan jumlah sampel yang digunakan, yaitu hanya mencakup lima periode, yaitu dari tahun 2014 hingga tahun 2018.

3. Adanya keterbatasan variabel independen yang pada penelitian ini hanya menggunakan ukuran perusahaan, leverage, profitabilitas, likuiditas, dewan direksi, dan komite audit.

\section{Rekomendasi}

Penulis memberikan sejumlah rekomendasi yang dapat dipertimbangkan oleh peneliti dalam melakukan penelitian berikutnya:

1. Peneliti dapat menambah dan memperluas ruang lingkup populasi 
penelitian dengan menggunakan sampel perusahaan dari negara lain selain negara Indonesia.

2. Peneliti dapat menambah dan memperluas periode penelitian menjadi lebih dari 5 periode.

3. Penelitian dapat dilangsungkan dengan memanfaatkan pengukuran yang berbeda dan memperbanyak variabel penelitian yang belum dipakai pada penelitian ini seperti pertumbuhan perusahaan, board ethnicity, umur perusahaan, kinerja keuangan, direktur wanita, tipe industri, gender diversity, ukuran dewan, dan independensi dewan.

\section{DAFTAR PUSTAKA}

Adhipradana, F., \& Daljono. (2013). Pengaruh Kinerja Keuangan, Ukuran Perusahaan dan Corporate Governance terhadap Pengungkapan Sustainabillitty Report. Diponegoro Journal of Accounting, 2, 1-10.

Almilia, L. S. (2008). Faktor-Faktor yang Mempengaruhi Pengungkapan Sukarela Internet Financial and Sustainability Reporting. Jurnal Akuntansi dan Auditing Indonesia, 12(2), 117-131.

Arens, A. A., Elder, R. J., \& Beasley, M. S. (2014). Auditing and Assurance Services: An Integrated Approach. Singapore: Pearson.

Artiach, T., Lee, D., Nelson, D., \& Walker, J. (2010). The determinants of corporate sustainability performance. Accounting and Finance, 50(1), 31-51.

Aziza, N. (2014). Anteseden Pengungkapan Lingkungan dan Pengaruhnya Terhadap Image Perusahaan, Jurnal Fairness. 4(1), 1-21.

Benjamin, U. D., Okpanachi, J., \& Muhammad, M. L. (2017). Effect of Firm Characteristics on Environmental Reporting Practices of Listed Manufacturing Firms In Nigeria. Nigerian Journal of Management Sciences, 6(1), 139-148.

Bhatia, A., \& Tuli, S. (2017). Corporate Attributes Affecting Sustainability
Reporting: an Indian Perspective. International Journal of Law and Management, 59(3), 322-340. https://doi.org/10.1108/IJLMA-11-20150057

Bradbury, M. E., Mak, Y. T., \& Tan, S. M. (2004). Board Characteristics, Audit Committee Characteristics and Abnormal Accruals. Accounting, Law and Finance, 6, 1-27.

Branco, M. C., Delgado, C., Gomes, S. F., \& Eugénio, T. C. P. (2014). Factors Influencing the Assurance of Sustainability Reports in the Context of the Economic Crisis in Portugal. Managerial Auditing Journal, 29(3), 237-252. https://doi.org/10.1108/MAJ07-2013-0905

Dewi, A. S. M., \& Wirajaya, A. (2013). Pengaruh Struktur Modal, Profitabilitas Dan Ukuran Perusahaan pada Nilai Perusahaan. E-Jurnal Akuntansi, 4(2), 358-372.

Dibia, N., \& Nwaigwe, N. (2018). Sustainable Development Practices and Corporate Financial Performance: A Survey of Selected Quoted Companies in Nigeria. Asian Journal of Economics, Business and Accounting, 7(1), 1-13. https://doi.org/10.9734/AJEBA/2018/40 995

Doktoralina, C. M., Anggraini, D., \& Melzatia, S. (2018). The Importance of Sustainability Reports In Non-Financial Companies. Journal of Accounting, 22(3), 368-384.

Elshabasy, Y. N. (2018). The Impact of Corporate Characteristics on Environmental Information Disclosure: an Empirical Study on the Listed Firms in Egypt. Journal of Business and Retail Management Research, 12(2), 232-241. https://doi.org/10.24052/jbrmr/v12is02/ti occoeidaesotlfie

Gallo, P. J., \& Christensen, L. J. (2011). Firm size matters: An Empirical Investigation of Organizational Size and Ownership on Sustainability-related Behaviors. Business and Society, 50(2), 315-349. https://doi.org/10.1177/00076503113987 
84

Hasanah, N., Syam, D., \& Jati, A. W. (2017). Pengaruh Corporate Governance terhadap Pengungkapan Sustainability Report pada Perusahaan di Indonesia. Jurnal Reviu Akuntansi Dan Keuangan, 5(1), 711-720.

Indriantoro, N., \& Supomo, B. (2002). Metodologi Penelitian Bisnis untuk Akuntansi dan Manajemen. Yogyakarta: BPFE-Yogyakarta.

Jan, S., \& Sangmi, M. (2016). The Role of Board of Directors in Corporate Governance. Imperial Journal of Interdisciplinary Research (IJIR), 2(5), 707-715.

Khafid, M. (2012). Kontribusi Karakteristik Perusahaan dan Corporate Governance terhadap Publikasi Sustainability Report. Jurnal Ekonomi dan Keuangan, (80), 340-359.

Legendre, S., \& Coderre, F. (2013). Determinants of GRI G3 Application Levels: The Case of the Fortune Global 500. Corporate Social Responsibility and Environmental Management, 20(3), 182-192.

https://doi.org/10.1002/csr.1285

Lucia, L., \& Panggabean, R. R. (2018). the Effect of Firm'S Characteristic and Corporate Governance To Sustainability Report Disclosure. Social Economics and Ecology International Journal (SEEIJ), 2(1), 18-28.

Makhdalena. (2019). Audit Committee, Foreign Ownership and Sustainability Report. Journal of Finance and Accounting, 10(4), 15-21.

Malik, M. (2014). Audit committee composition and effectiveness: a review of post-SOX literature. Journal of Management Control, 25(2), 81-117.

Molz, R. (2007). The Role of the Board of Directors: Typologies of Interaction. Journal of Business Strategy, 5(4), 8693.

Naidia, R., Wulandari, A., \& Septiani, A. (2017). Pengaruh Ukuran Perusahaan, Profitabilitas Dan Leverage terhadap Sustainability Disclosure. Journal of
Accounting, 6(4), 472-480.

O'Donovan, G. (2002). Environmental disclosures in the annual report. Accounting, Auditing \& Accountability Journal, 15(3), 345-371.

Paramita, S., \& Chariri, A. (2013). Determinan dan Konsekuensi Investasi Lingkungan. Journal of Accounting, 2(2), 1-13.

Prasetyorini, B. F. (2013). Pengaruh Ukuran Perusahaan, Leverage, Price Earning Ratio dan Profitabilitas terhadap Nilai Perusahaan. Jurnal Ilmu Manajemen (JIM), l(1).

Puspasari, A. (2017). Rasio Likuiditas dan Profitabilitas pada PT. Kalbe Farma Bekasi, (102), 15-26.

Saifi, M., \& Hanie, U. P. (2018). Studi Pada Perusahaan Indeks LQ45 Periode 20142016. Jurnal Administrasi Bisnis (JAB), 58(1), 95-102.

Saputro, D. A., Fachrurrozie, \& Agustina, L. (2013). Pengaruh Kinerja Keuangan terhadap Pengungkapan Sustainability Report Perusahaan di Bursa Efek IndonesIa, 2(4), 480-488.

Sari, M. P. Y. (2013). Governance Terhadap Pengungkapan Sustainability Report. Journal of Accounting, 3(2).

Sari, M. P. Y., \& Marsono. (2013). Pengaruh Kinerja Keuangan, Ukuran Perusahaan dan Corporate Governance Terhadap Pengungkapan Sustainability Report. Journal of Accounting, 2(3), 1-10.

Sastrawan, I., \& Latrini, M. (2016). Pengaruh Profitabilitas, Solvabilitas, Dan Ukuran Perusahaan Terhadap Audit Report Lag Pada Perusahaan Manufaktur. E-Jurnal Akuntansi, 17(1), 311-337.

Shum, P., Chen, H., \& Burritt, R. L. (2009). A cross-country study of the determinants of sustainability reporting and assurance. South American Congress on Social and Environmental Accounting Research, 1-26.

Sinaga, K. J., \& Fachrurrozie. (2017). The Effect of Profitability, Activity Analysis, Industrial Type and Good Corporate Governance Mechanism on The Disclosure of Sustainability Report. 
Accounting Analysis Journal, 6(3), 347358.

https://doi.org/10.15294/aaj.v6i3.18690

Sudarmadji, A. M., \& Sularto, L. (2007).

Pengaruh ukuran perusahaan,

profitabilitas, leverage, dan tipe kepemilikan perusahaan terhadap luas, 2 , 21-22.

Suryono, H., \& Prastiwi, A. (2011). Pengaruh Karakteristik Perusahaan dan Corporate Governance Terhadap Praktik Pengungkapan Sustainability Report (SR): Studi pada Perusahaan-Perusahaan yang Listed (Go-Public) di Bursa Efek Indonesia (BEI) periode 2007-2009. Simposium Nasional Akuntansi XIV Aceh 2011, 21-22.

Tulsian, D. M. (2014). Profitability Analysis (A comparative study of SAIL \& TATA Steel). IOSR Journal of Economics and Finance, 3(2), 19-22.

Yasmin, N., \& Zuraida, Z. (2017). Determinants of Sustainability Disclosure: Evidence from NonFinancial Companies Listed On the Indonesia Stock Exchange 2013-2015. Prosiding Seminar Nasional Pascasarjana (SNP) Unsyiah, 139-149. 